\title{
Ring contraction versus $\beta$-elimination in reactions of alkynyl-substituted bicyclic lactol esters with $\mathrm{SmI}_{2} / \mathbf{P d}(0)$
}

\author{
José M. Aurrecoechea* , Roberto Fañanás and Beatriz López \\ Departamento de Química Orgánica, Facultad de Ciencias, Universidad del País Vasco, \\ Apartado 644, 48080 Bilbao, Spain \\ E-mail: qopaufem@lg.ehu.es
}

(received 14 Feb 00; accepted 25 Apr 00; published on the web 03 May 00)

\begin{abstract}
Selective addition of alkynyl metal reagents to either carbonyl group of 2-(2formylethyl)cycloalkanones afforded alkynyl-substituted bicyclic lactols that were further converted into the corresponding acetate or benzoate esters. Reactions of these bicyclic esters with $\mathrm{SmI}_{2} / \mathrm{Pd}\left(\mathrm{PPh}_{3}\right)_{4}$ displayed a divergent behavior which was dependent on the degree of substitution at the alkynyl terminus as well as on the bicycle ring size. Thus, 2oxabicyclo[4.3.0]nonanes with terminal alkynes gave ring contracted bicyclic alcohols whereas the presence of substituents at the alkynyl terminus or the use of higher bicycloalkane homologues led to enol ethers, as the result of Lewis acid-promoted $\beta$-elimination.
\end{abstract}

Keywords: Lactol esters, samarium iodide, palladium(o), $\beta$-elimination

\section{Introduction}

We have recently reported on the intramolecular propargylation of carbonyl compounds using the umpolung of propargylic esters I with $\mathrm{SmI}_{2} / \mathrm{Pd}(0) .{ }^{1-2}$ This reaction is thought to involve the initial formation of an allenylpalladium complex II that is rapidly reduced to an equilibrium mixture of allenic (V) and propargylic (VI) organosamarium intermediates that finally add to the carbonyl group (Scheme 1). ${ }^{3}$

Therefore, in this reaction the propargylic acetate acts as a synthetic equivalent of the propargyl anion synthon. As an extension of this chemistry, we have described the alternative use of acetals (III, $\left.\mathrm{R}^{1}-\mathrm{R}^{3}=\mathrm{H}\right)$ and esters $\left(\mathbf{I V}, \mathrm{R}^{1}-\mathrm{R}^{3}=\mathrm{H}\right)$, derived from structurally related lactols, to convert a carbohydrate to carbocycle via a ring contraction of the carbohydrate that

presumably proceeds through the same intermediates. ${ }^{4-6}$ We aimed to apply this last reaction to bicyclic substrates $\mathbf{1 , 2}$ and $\mathbf{4}$. These would presumably afford the bicyclic alcohols $\mathbf{3}$ and 5 (Scheme 2) and this paper reports on the results of that study. ${ }^{7}$ 


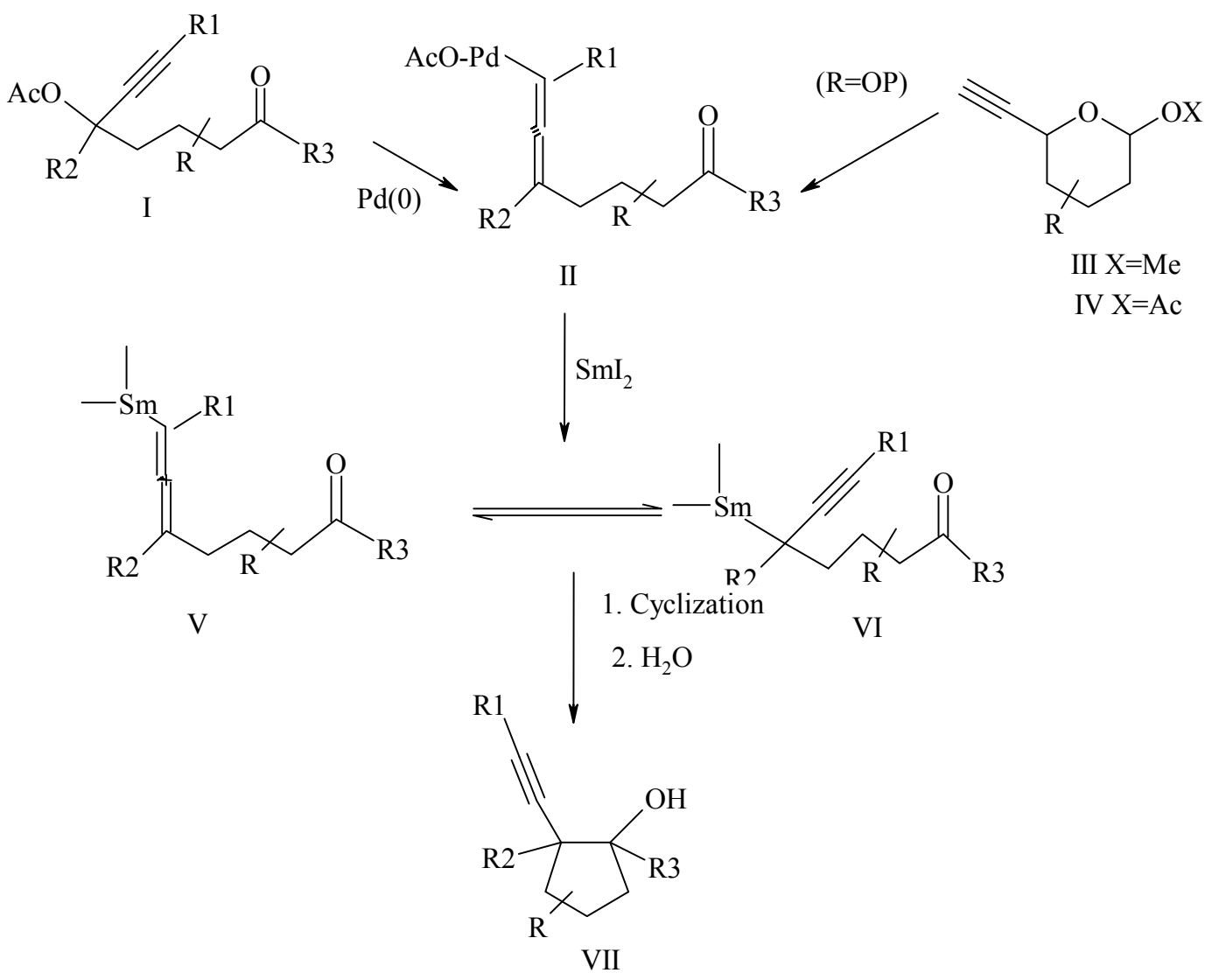

\section{Scheme 1}

\section{Results and Discussion}

Synthesis of starting materials. The representative substrates 1,2 and 4 were prepared using ketoaldehydes $\mathbf{6}$ as common starting materials (Scheme 3, Table 1). The method initially selected involved in situ protection of the al dehyde carbonyl using tetrakis(diethylamino)titanium according to the procedure developed by Reetz, ${ }^{8}$ followed by addition to the ketone to give lactols 7. This procedure worked well for additions to cyclohexanone 6a (Table 1, entries 1-3) but failed when cyclopentanone $\mathbf{6 b}$ was used. 

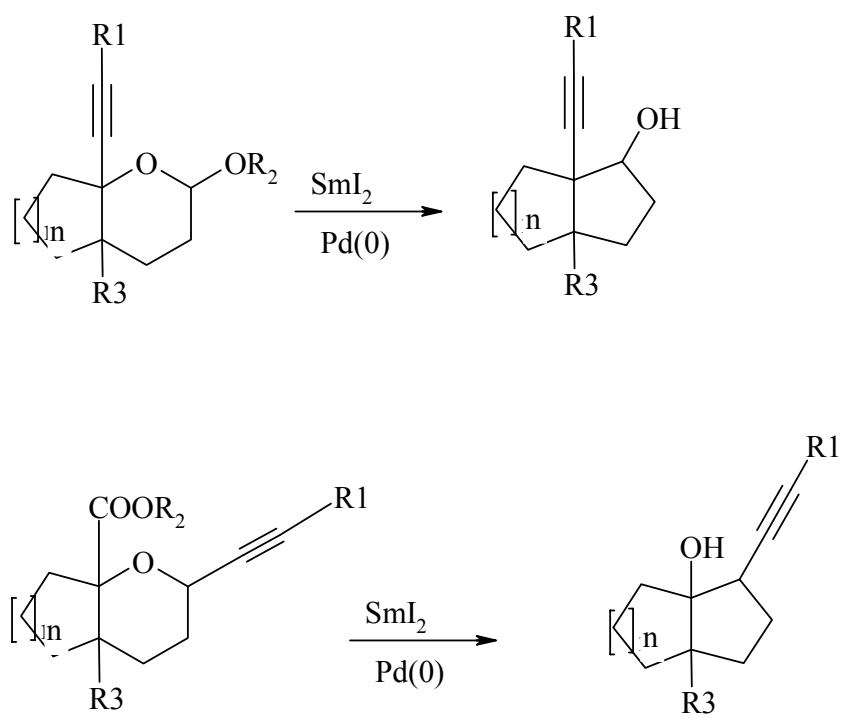

\section{Scheme 2}

Table 1. Preparation of Acetates 1 from Ketoaldehydes 6

\begin{tabular}{cccccc}
\hline & $\mathbf{6}$ & $\mathrm{R}-\equiv-\mathrm{M}$ & $7(\%)$ & $1(\%)$ & Cis/trans $^{\text {a }}$ Ratio \\
\hline 1 & $\mathbf{6 a}^{\mathbf{b}}$ & $\mathrm{H}-\equiv-\mathrm{MgBr}$ & $\mathbf{7 a}$ & $\mathbf{1 a}(71)^{\mathrm{c}}$ & Cis only \\
2 & $\mathbf{6 a}^{\mathbf{b}}$ & $\mathrm{TMS}-=-\mathrm{Li}$ & $\mathbf{7 b}(84)$ & $\mathbf{1 b}(69)$ & $63: 37$ \\
3 & $\mathbf{6 a}^{\mathbf{b}}$ & $\mathrm{Ph}-=-\mathrm{Li}$ & $\mathbf{7 c}$ & $\mathbf{1 c}(54)^{\mathrm{c}}$ & $79: 21$ \\
4 & $\mathbf{6 b}^{\mathbf{d}}$ & $\mathrm{H}-\equiv-\mathrm{Li}$ & $\mathbf{7 d}(44)$ & $\mathbf{1 d}(87)$ & Trans only \\
5 & $\mathbf{6 b}^{\mathbf{e}}$ & $\mathrm{n}-\mathrm{Hex}-=-\mathrm{Li}$ & $\mathbf{7 e}(33)$ & $\mathbf{1 e}(89)$ & $\mathrm{f}$ \\
\hline
\end{tabular}

${ }^{\text {a }}$ Cis/trans refers to ring fusion. Ratio determined by ${ }^{1} \mathrm{H}$ NMR integration or from isolated weights of individual isomers. ${ }^{b}$ Protection method: $\mathrm{Ti}\left(\mathrm{NEt}_{2}\right)_{4},-78{ }^{\circ} \mathrm{C}$, then $-52-(-43){ }^{\circ} \mathrm{C}$. ${ }^{\mathrm{c}}$ Yield for two steps starting from $6 \mathrm{a} .{ }^{\mathrm{d}}$ Protection method: dibenzylamine, benzotriazole, $4 \AA$ molecular sieves, $25{ }^{\circ} \mathrm{C}$, work-up. ${ }^{\mathrm{e}}$ Protection method: cyclohexylamine, $25{ }^{\circ} \mathrm{C}$, work-up. ${ }^{\mathrm{f}} \mathrm{An}$ approximate 20:1 diastereoisomer ratio.

In this case the starting ketoaldehyde was recovered unchanged. Alternatively, protection of the aldehyde carbonyl of $\mathbf{6 b}$ as either a $N$-(dibenzylaminoalkyl)benzotriazole ${ }^{9}$ or $N$-cyclohexyl imine followed by addition of appropriate alkynyl lithium or magnesium derivatives to the remaining ketone carbonyl afforded moderate yields of lactols 7d,e (Table 1, entries 4,5). Lactols 7 were obtained with moderate to high diastereoselectivity. Acetylation of the lactols using standard conditions afforded in all cases good yields of acetates $\mathbf{1}$. Alternatively, treatment of lactol $\mathbf{7 a}$ with $\mathrm{HCl} / \mathrm{MeOH}$ led to the corresponding acetal $\mathbf{2}$ as a single diastereoisomer (Scheme $3)$. 

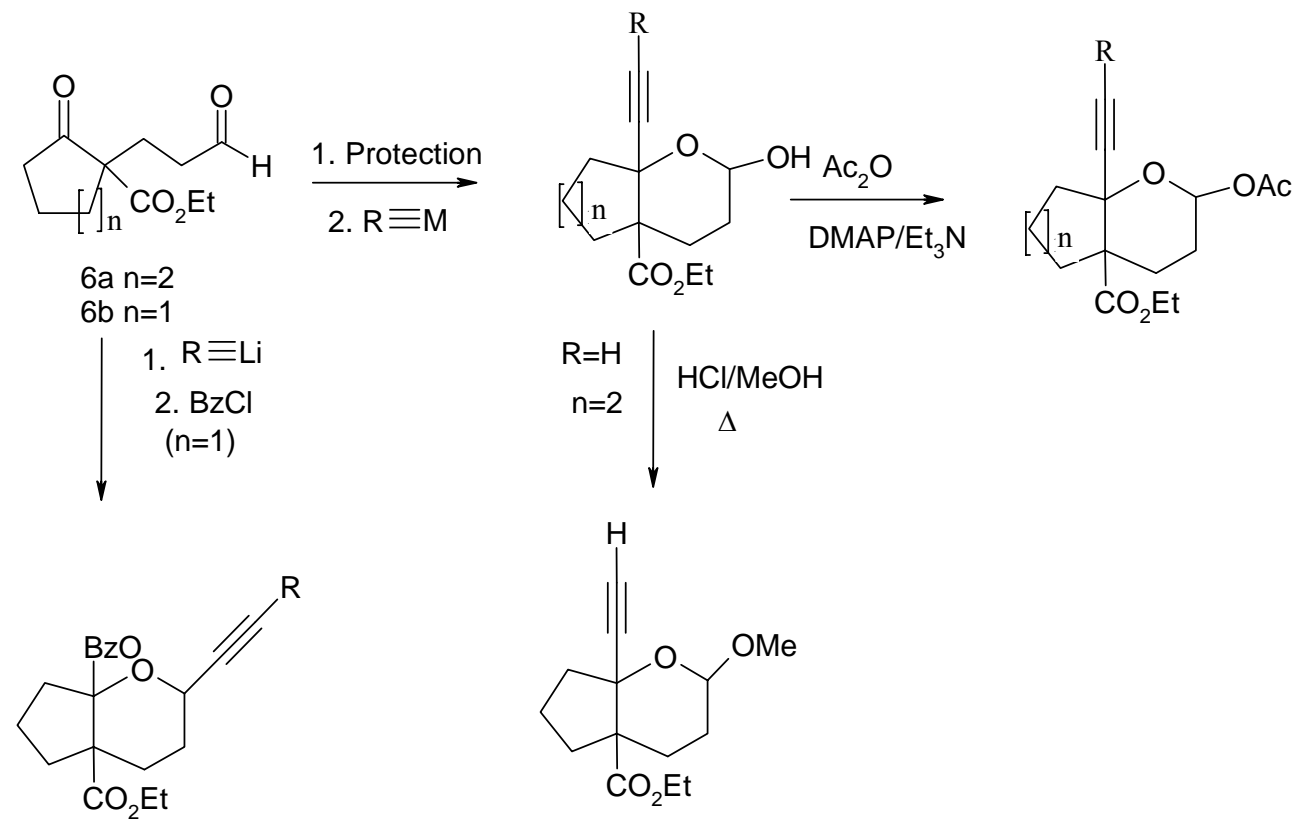

$4 \mathrm{a} \mathrm{R}=\mathrm{H}(35 \%)$

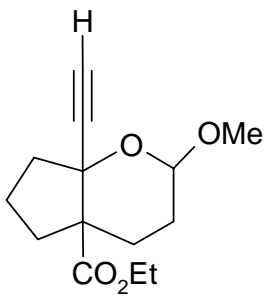

$2(79 \%)$

$4 \mathrm{~b} R=\mathrm{R}-\mathrm{Bu}(30 \%)$

\section{Scheme 3}

For the synthesis of $\mathbf{4}$, the ketoaldehyde $\mathbf{6 b}$ was directly treated with the required alkynyl lithium and the resulting alkoxide intermediate was trapped with benzoyl chloride to afford moderate yields of benzoates 4 . Two out of four isomers were observed at most for 1,2 and 4 . The stereochemistry of ring fusion has been determined for both isomers of $\mathbf{1 c}$ and the assignments were extended by analogy to $\mathbf{1 a}, \mathbf{1 b}, \mathbf{1 d}$ and $\mathbf{2}$. Thus, the major isomer of 1c, derived from cyclohexanone 6a, was assigned a cis-ring fusion based on the observed coupling constants $(J)$ for its $\mathrm{H}-4$ proton in the ${ }^{1} \mathrm{H}$ NMR spectrum (Table 2). 
Table 2. Coupling constants $J$ (in $\mathrm{Hz}$ ) for $\mathrm{H}-4$ in 1 and 2

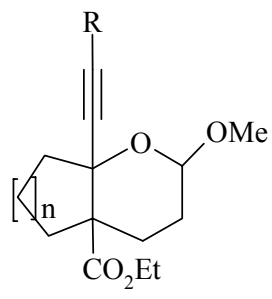

Major 1-c

Major 2

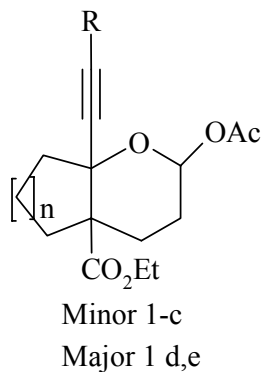

Major $1 \mathrm{~d}, \mathrm{e}$

\begin{tabular}{lllll}
\hline $\mathrm{n}(\mathbf{1}, \mathbf{2})$ & $\mathrm{R}$ & $\mathrm{X}$ & Major isomer & Minor isomer \\
\hline $2(\mathbf{1 a})$ & $\mathrm{H}$ & $\mathrm{Ac}$ & $\mathrm{m}$ & - \\
$2(\mathbf{1 b})$ & $\mathrm{TMS}$ & $\mathrm{Ac}$ & $\mathrm{m}$ & $\mathrm{dd}$ \\
& & & & $(10.2,2.9)$ \\
$2(\mathbf{1 c})$ & $\mathrm{Ph}$ & $\mathrm{Ac}$ & $\mathrm{dd}$ & $\mathrm{dd}$ \\
& & & $(7.3,5.4) \mathrm{a}$ & $(10.1,3.1)$ \\
$1(\mathbf{1 d})$ & $\mathrm{H}$ & $\mathrm{Ac}$ & $\mathrm{dd}$ & - \\
& & & $(9.7,2.7)$ & \\
$1(\mathbf{1 e})$ & $n-\mathrm{Bu}$ & $\mathrm{Ac}$ & $\begin{array}{l}\mathrm{dd} \\
(9.8,2.6)\end{array}$ & - \\
$2(\mathbf{2})$ & $\mathrm{H}$ & $\mathrm{Me}$ & $\mathrm{m}$ & - \\
\hline
\end{tabular}

These values were intermediate between those expected for axial and equatorial dispositions of that proton. This assignment was confirmed by the temperature dependence shown by the apparent $J$ values of H-4 in that isomer (see Table 2). This indicated a flexible conformation only compatible with a cis ring junction. This analysis did not allow, however, an unambiguous configurational assignment for C-4. On the other hand, H-4 in minor 1c appeared in the ${ }^{1} \mathrm{H}$ NMR spectrum as doublet of doublets with $J=10.1,3.1 \mathrm{~Hz}$. This signal remained unchanged over a temperature interval between -30 and $58{ }^{\circ} \mathrm{C}$ and this was taken as an indication of a rigid trans ring fusion with an axial disposition for H-4. According to this analysis, the major isomers of cyclopentanone-derived 1d,e would present trans ring junctions as indicated by their H-4 $J$ values ( 10 and $3 \mathrm{~Hz}$ ). No stereochemical assignment was made for 4a,b.

Reactions with $\mathrm{SmI}_{2} / \mathbf{P d}(\mathbf{0})$. The major isomers of lactol esters 1 and $\mathbf{4}$ were independently treated with 2.2 equivalents of $\mathrm{SmI}_{2}$ and a catalytic amount of $\mathrm{Pd}\left(\mathrm{PPh}_{3}\right)_{4}(5 \mathrm{~mol} \%)$ at room temperature. The results were drastically dependent on the type of substrate employed and the presence or absence of substituents at the terminal alkynyl position (Scheme 4, Table 3). 
<smiles>[R]C#CC12CCCCC1(C#C[R])C(C#CC)(C(=O)OCC)CCC(OC(C)=O)O2</smiles><smiles>[R]C#C[C@]12CCCC1(C(=O)OCC)CCC(O)O2</smiles>

$1 \mathrm{~d}, \mathrm{e}$

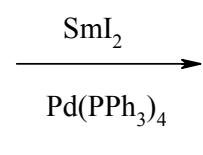

$\mathrm{Pd}\left(\mathrm{PPh}_{3}\right)_{4}$

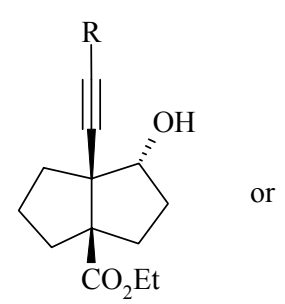

$3 d$<smiles>[R]C#C[C@]12CCCC1(C(=O)OCC)CC=CO2</smiles>

$8 \mathrm{e}$

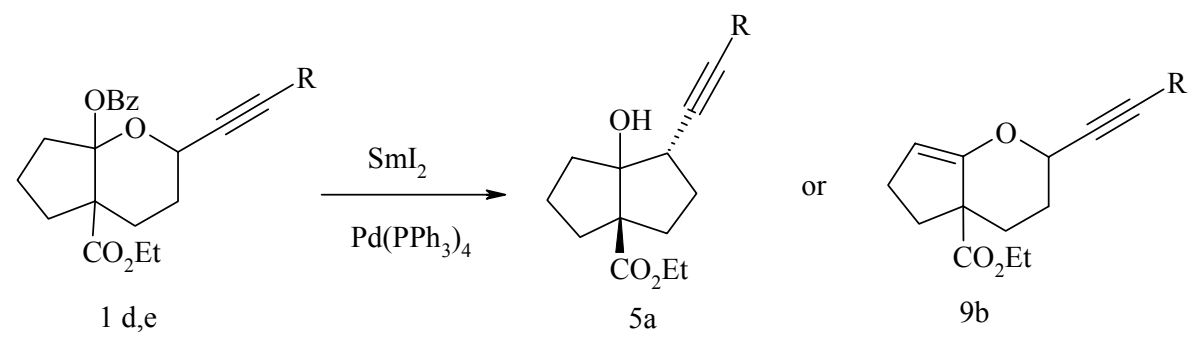

\section{Scheme 4}

Thus, for cyclopentanone-derived substrates 1d and 4a, with a terminal alkyne, a slow reaction was observed that led to the formation of bicyclic alcohols 3d and 5a, respectively, with good yields and excellent stereoselectivities. However, the reaction took a completely different course when a terminal alkynyl substituent was present in the substrate, as in $\mathbf{1 e}$ and $\mathbf{4 b}$. In those cases the only reaction products isolated were the enol ethers $\mathbf{8 e}$ and $\mathbf{9 b}$, respectively. Similarly, the reactions of the cyclohexanone-derived 1a-c led predominantly to enol ethers 8a-c, accompanied occasionally by lactols 7 , probably the result of hydrolysis of $\mathbf{8}$ during work-up. The formation of enol ethers 8 does not require the presence of $\operatorname{Pd}(0)$ in the medium, as indicated by the result of entry 3 in Table 3 . The acetal 2 was inert in the presence of $\mathrm{SmI}_{2} / \mathrm{Pd}\left(\mathrm{PPh}_{3}\right)_{4}$ even under refluxing conditions. 
Table 3. Reactions of 1 and 4 with $\mathrm{SmI}_{2} / \mathrm{Pd}\left(\mathrm{PPh}_{3}\right)_{4}$

\begin{tabular}{ccccc}
\hline & $\mathbf{1}^{\mathrm{a}}$ & $\mathrm{R}$ & Product & Yield (\%) \\
\hline 1 & $\mathbf{1 a}$ & $\mathrm{H}$ & $\mathbf{8 a}^{\mathrm{b}}$ & 65 \\
2 & $\mathbf{1 b}$ & $\mathrm{TMS}$ & $\mathbf{8 b}$ & 63 \\
3 & $\mathbf{1 c}^{\mathrm{c}}$ & $\mathrm{Ph}$ & $\mathbf{8 c}$ & 78 \\
4 & $\mathbf{1 d}$ & $\mathrm{H}$ & $\mathbf{3 d}$ & 84 \\
5 & $\mathbf{1 e}$ & $n-\mathrm{Bu}$ & $\mathbf{8 e}$ & 88 \\
6 & $\mathbf{4 a}$ & $\mathrm{H}$ & $\mathbf{5 a}$ & 73 \\
7 & $\mathbf{4 b}$ & $n-\mathrm{Bu}$ & $\mathbf{9 b}$ & $37^{\mathrm{d}}$ \\
\hline
\end{tabular}

${ }^{\mathrm{a}}$ Major isomers. ${ }^{\mathrm{b}}$ Also obtained was 7a $(6 \%) .{ }^{\mathrm{c}} \mathrm{Pd}\left(\mathrm{PPh}_{3}\right)_{4}$ was not used. ${ }^{\mathrm{d}}$ Starting material was recovered $(32 \%)$.

The stereochemical assignment of $\mathbf{3 d}$ followed from the chemical shift differences found in the carbinolic protons of the diastereomeric mixture of alcohols 3d and 3d' obtained after $\mathrm{NaBH}_{4}$ reduction of the ketone $\mathbf{1 0}$ that resulted from the PDC oxidation of 3d (Scheme 5). Thus, H-4 of 3d resonated at $\delta 4.37$ whereas the corresponding proton in 3d', buried in the concave face of the bicyclic structure, was found further upfield at $\delta 3.8-3.9$. The bicycle 5 a obtained from 4 a was identical in all physical properties to the previously reported material prepared using the route $\mathbf{I}$ $\rightarrow$ VII (Scheme 1). ${ }^{1}$

$3 \mathrm{~d}$

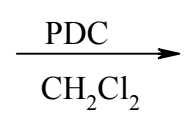

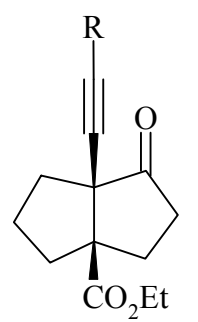

10

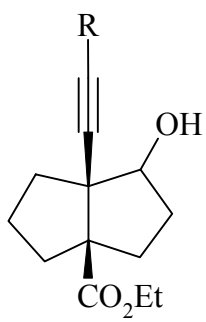

$3 \mathrm{~d}^{\prime}$

\section{Scheme 5}

\section{Results and Discussion}

Carbohydrate-derived monocyclic acetals and esters related to 1, 2 and $\mathbf{4}$ have been employed in ring raction reactions leading to 2-alkynylcyclopentanols, ${ }^{5,6}$ a transformation that is readily understood in the mechanistic terms shown in Scheme 1. This reaction is facilitated by Lewis acidic Sm(III) species, inevitably present in the reaction medium, that activate the leaving group (OMe or OCOR) and bring about the initial oxidative addition step that begins the catalytic cycle. Always latent in these reactions is the possibility of $\beta$-elimination promoted by the same 
Lewis acids or even by $\mathrm{SmI}_{2}{ }^{10}$ In monocyclic systems with terminal alkynes the oxidative addition is reasonably fast and, as a result, ring opening is favored over $\beta$-elimination. ${ }^{5,6}$ This also seems to be the case with cyclopentanone-derived substrates $\mathbf{1 d}$ and $\mathbf{4 a}$. If, on the other hand, the oxidative addition step becomes slower due to the presence of terminal alkynyl substituents, then $\beta$-elimination takes over as it is observed in the reactions of $\mathbf{1 e}$ and $\mathbf{4 b}$. However, it is also apparent from the strikingly different results observed for 1a and 1d, that the size of the rings containing the bridgehead propargylic position, as well as the axial or equatorial orientation of the leaving group, are also probably important to the outcome of the reaction. Thus, $\beta$-elimination from the equatorial leaving group of the conformationally rigid bicycle 1d is expected to be slower than from the much more flexible bicycle 1a where both axial and equatorial orientations of the leaving group are possible at any given time. Additionally, the hybridization change in cyclopentanone-derived 1d in going to an intermediate related to II (Scheme 1) should be more favorable than that taking place in cyclohexanone-derived 1a. Taken together, all these factors give as a result a preferred $\beta$-elimination pathway for $\mathbf{1 a}-\mathbf{c}$.

\section{Conclusions}

The $\mathrm{SmI}_{2} / \mathrm{Pd}(0)$-promoted ring contraction of bicyclic lactol esters leads to the expected bicyclic homopropargyl alcohols only when the oxidative addition that initiates the reaction competes efficiently with the alternative Lewis acid-promoted $\beta$-elimination. The synthetic potential of the ring contraction process for the preparation of bicyclic systems is significantly restricted by factors that adversely affect oxidative addition, namely (i) the presence of terminal alkynyl substituents and (ii) the development of torsional strain upon ring opening. At the same time, $\beta$ elimination is facilitated by axial leaving groups with an antiperiplanar $\beta$-hydrogen.

\section{Experimental Section}

General Procedures. All reactions involving air- and moisture-sensitive materials were performed using standard bench-top techniques. ${ }^{11}$ Diiodoethane was purified as reported. ${ }^{12}$ Tetrahydrofuran (THF) was freshly distilled from sodium/benzophenone and, for reactions with $\mathrm{SmI}_{2}$, it was deoxygenated prior to use. Other solvents were routinely purified using literature procedures. ${ }^{13}$ Flash column chromatography ${ }^{14}$ was performed on silica gel (230-400 mesh). HPLC purifications were carried out with either a LiChrosorb Si60 (7 $\mu \mathrm{m}, 25$ x $2.5 \mathrm{~cm}$, column 1) or a $\mu$ Porasil $(10 \mu \mathrm{m}, 19 \times 1.5 \mathrm{~cm}$, column 2$)$ column using a refractive index detector. Routine ${ }^{1} \mathrm{H}$ and ${ }^{13} \mathrm{C}$ NMR spectra were obtained at $250 \mathrm{MHz}$ and $62.9 \mathrm{MHz}$, respectively, using $\mathrm{CDCl}_{3}$ as solvent and internal reference $\left(\delta 7.26\right.$ for ${ }^{1} \mathrm{H}$ and $\delta 77.0$ for $\left.{ }^{13} \mathrm{C}\right)$. IR data include only characteristic absorptions. Mass spectra were obtained at $70 \mathrm{eV}$. 
Ethyl 4-acetoxy-6-ethynyl-cis-5-oxabicyclo[4.4.0]decanecarboxylate (1a). To a stirred solution of $\mathbf{6 a}^{15}$ (543 $\left.\mathrm{mg}, 2.40 \mathrm{mmol}\right)$ in THF $(19 \mathrm{~mL})$ at $-78{ }^{\circ} \mathrm{C}$ was added dropwise $\mathrm{Ti}\left(\mathrm{NEt}_{2}\right)_{4}$ $(880 \mu \mathrm{L}, 2.43 \mathrm{mmol})$. The mixture was allowed to reach $-43{ }^{\circ} \mathrm{C}$ over a period of $1 \mathrm{~h}$, and ethynylmagnesium bromide $(0.5 \mathrm{M}$ in THF, $9.8 \mathrm{~mL}, 4.90 \mathrm{mmol})$ was added dropwise. The resulting solution was stirred at the same temperature for $14 \mathrm{~h}$ and quenched with $1 \mathrm{M} \mathrm{HCl} \mathrm{(19}$ $\mathrm{mL})$. The aqueous layer was extracted with EtOAc $(3 \times 45 \mathrm{~mL})$ and the combined organic extracts were washed with brine $(6 \mathrm{~mL})$ and dried $\left(\mathrm{Na}_{2} \mathrm{SO}_{4}\right)$. The crude after evaporation of the solvent was dissolved in triethylamine $(1.20 \mathrm{~mL}, 8.61 \mathrm{mmol})$ and treated with acetic anhydride $(680 \mu \mathrm{L}, 7.20 \mathrm{mmol})$ and then DMAP $(90 \mathrm{mg}, 0.73 \mathrm{mmol})$. The mixture was stirred at room temperature for $15 \mathrm{~h}$, diluted with $\mathrm{Et}_{2} \mathrm{O}(80 \mathrm{~mL})$ and poured over ice-water $(8 \mathrm{~mL})$. The aqueous layer was extracted with $\mathrm{Et}_{2} \mathrm{O}(3 \times 20 \mathrm{~mL})$ and the combined organic layers were successively washed with $1 \mathrm{M} \mathrm{HCl}(10 \mathrm{~mL}), 1 \mathrm{M} \mathrm{NaOH}(9 \mathrm{~mL}), \mathrm{H}_{2} \mathrm{O}(6 \mathrm{~mL})$ and brine $(6 \mathrm{~mL})$. After drying $\left(\mathrm{Na}_{2} \mathrm{SO}_{4}\right)$ and evaporation of the solvents the resulting residue was purified by flash chromatography (silica gel, 15\% EtOAc in hexanes) to afford 1a (473 $\mathrm{mg}, 71 \%$ ) as a colorless oil: ${ }^{1} \mathrm{H}$ NMR $\delta 1.25\left(\mathrm{t}, J=7.1 \mathrm{~Hz}, 3 \mathrm{H}, \mathrm{CO}_{2} \mathrm{CH}_{2} \mathrm{CH}_{3}\right), 1.38-2.24(\mathrm{~m}, 13 \mathrm{H}), 2.10\left(\mathrm{~s}, \mathrm{OCOCH}_{3}\right.$, included in $\mathrm{m}$ at 1.38-2.24), 2.24-2.37 (m, 1H), $2.49(\mathrm{td}, J=13.5,4.8 \mathrm{~Hz}, 1 \mathrm{H}), 2.60(\mathrm{~s}, 1 \mathrm{H}, \mathrm{H}-$ $\left.2^{\prime}\right), 4.16$ (q, $\left.J=7.1 \mathrm{~Hz}, 2 \mathrm{H}, \mathrm{CO}_{2} \mathrm{CH}_{2} \mathrm{CH}_{3}\right), 6.21-6.26$ (m, 1H, H-4); ${ }^{13} \mathrm{C}$ NMR $\delta 14.0,20.0,21.2$, 21.6, 28.2, 28.6, 35.4, 47.3, 60.5, 73.9, 75.6, 82.7, 92.6, 169.1, 173.4; IR (neat) v 3260, 2109, 1753, $1725 \mathrm{~cm}^{-1}$; HRMS calcd for $\mathrm{C}_{16} \mathrm{H}_{22} \mathrm{O}_{5} 294.1467$, found 294.1478.

Alternatively, the crude obtained in the reaction with ethynylmagnesium bromide was purified by flash chromatography (silica gel, 15\% EtOAc in hexanes) to yield ethyl 4-hydroxy-6ethynyl-cis-5-oxabicyclo[4.4.0]decanecarboxylate (7a) (42\%, one isomer). The analytical sample was obtained after additional purification by HPLC (column 1, 30\% EtOAc in hexanes, $10 \mathrm{~mL} / \mathrm{min}): t_{\mathrm{R}} 20 \mathrm{~min} ;{ }^{1} \mathrm{H}$ NMR $\delta 1.22-1.95(\mathrm{~m}, 12 \mathrm{H}), 1.25\left(\mathrm{t}, J=7.1 \mathrm{~Hz}, \mathrm{CO}_{2} \mathrm{CH}_{2} \mathrm{CH}_{3}\right.$, included in $\mathrm{m}$ at 1.22-1.95), 2.03-2.31 (m, 2H), 2.43-2.56 (m, 2H), $2.53(\mathrm{~s}, \mathrm{H}-2$ ', included in $\mathrm{m}$ at 2.43-2.56), $3.33(\mathrm{~d}, J=5.7 \mathrm{~Hz}, 1 \mathrm{H}, \mathrm{OH}), 4.15\left(\mathrm{q}, J=7.1 \mathrm{~Hz}, 2 \mathrm{H}, \mathrm{CO}_{2} \mathrm{CH}_{2} \mathrm{CH}_{3}\right), 5.35$ (ddd, $J$ $=9.7,5.7,3.0 \mathrm{~Hz}, 1 \mathrm{H}, \mathrm{H}-4) ;{ }^{13} \mathrm{C} \mathrm{NMR} \delta 14.0,20.1,21.7,27.9,28.2,28.9,35.8,47.3,60.5,73.0$, 75.0, 83.7, 93.3; IR (KBr) v 3370, 3240, 2085, $1735 \mathrm{~cm}^{-1}$. Anal. Calcd for $\mathrm{C}_{14} \mathrm{H}_{20} \mathrm{O}_{4}$ : C, 66.63; H, 7.99. Found: C, 66.51; H, 7.87.

Ethyl 4-acetoxy-6-(trimethylsilylethynyl)-5-oxabicyclo[4.4.0]decanecarboxylate (1b). The procedure described for the synthesis of $\mathbf{1 a}$ was followed from $\mathbf{6 a}^{15}(521 \mathrm{mg}, 2.30 \mathrm{mmol})$ and lithium (trimethylsilyl)acetylide $(\sim 0.27 \mathrm{M}, 2.85 \mathrm{mmol})$. Reaction time : $1.2 \mathrm{~h}$ at $-45{ }^{\circ} \mathrm{C}$. The intermediate lactols were purified by flash chromatography (silica gel, 20\% EtOAc in hexanes, then 30\% EtOAc in hexanes) and then acetylated individually as described for 1a. The acetate derived from the major lactol was purified by flash chromatography (silica gel, 5\% EtOAc in hexanes) to afford cis-1b (295 mg, 35\% from 6a) as a colorless oil. The acetate derived from the minor lactol was purified by flash chromatography (silica gel, 8\% EtOAc in hexanes, then 10\% EtOAc in hexanes) and HPLC (column 1, 10\% EtOAc in hexanes, $8 \mathrm{~mL} / \mathrm{min}, t_{\mathrm{R}} 32 \mathrm{~min}$ ) to yield trans-1b $\left(173 \mathrm{mg}, 23 \%\right.$ from 6a). Data for cis-1b: ${ }^{1} \mathrm{H} \mathrm{NMR} \delta 0.15\left(\mathrm{~s}, 9 \mathrm{H}, \mathrm{Si}\left(\mathrm{CH}_{3}\right)_{3}\right), 1.26(\mathrm{t}, J=$ $\left.7.1 \mathrm{~Hz}, 3 \mathrm{H}, \mathrm{CO}_{2} \mathrm{CH}_{2} \mathrm{CH}_{3}\right), 1.50-2.13(\mathrm{~m}, 14 \mathrm{H}), 2.09\left(\mathrm{~s}, \mathrm{OCOCH}_{3}\right.$, included in $\mathrm{m}$ at 1.50-2.13), 
2.24-2.51 (m, 2H), 4.14 (q, $\left.J=7.1 \mathrm{~Hz}, 2 \mathrm{H}, \mathrm{CO}_{2} \mathrm{CH}_{2} \mathrm{CH}_{3}\right), 6.20-6.26(\mathrm{~m}, 1 \mathrm{H}, \mathrm{H}-4) ;{ }^{13} \mathrm{C}$ NMR $\delta$ $-0.2,14.1,20.0,21.2,21.5,28.2,28.7,35.3,47.3,60.4,74.3,92.3,92.6,104.4,169.1,173.5$; IR (neat) v 2160, 1760, $1730 \mathrm{~cm}^{-1}$. Anal. Calcd for $\mathrm{C}_{19} \mathrm{H}_{30} \mathrm{O}_{5} \mathrm{Si}$ : C, 62.26; H, 8.26. Found: $\mathrm{C}, 62.32$; $\mathrm{H}, 8.14$. Data for trans-1b: ${ }^{1} \mathrm{H}$ NMR $\delta-0.21\left(\mathrm{~s}, 9 \mathrm{H}, \mathrm{Si}\left(\mathrm{CH}_{3}\right)_{3}\right), 1.08-1.30(\mathrm{~m}, 4 \mathrm{H}), 1.27(\mathrm{t}, J=$ $7.1 \mathrm{~Hz}, \mathrm{CO}_{2} \mathrm{CH}_{2} \mathrm{CH}_{3}$, included in $\mathrm{m}$ at $\left.1.08-1.30\right), 1.37-2.17(\mathrm{~m}, 13 \mathrm{H}), 2.08\left(\mathrm{~s}, \mathrm{OCOCH}_{3}\right.$, included in $\mathrm{m}$ at $1.37-2.17), 2.63-2.75(\mathrm{~m}, 1 \mathrm{H}), 4.10-4.24\left(\mathrm{~m}, 2 \mathrm{H}, \mathrm{CO}_{2} \mathrm{CH}_{2} \mathrm{CH}_{3}\right), 6.40$ (dd, $J=$ 10.2, $2.9 \mathrm{~Hz}, 1 \mathrm{H}, \mathrm{H}-4) ;{ }^{13} \mathrm{C}$ NMR $\left.\delta-0.31,14.1,21.1,22.0,22.9,27.9,30.2,33.0,49.3\right), 60.1$, 78.4, 92.4, 94.9, 103.9, 169.0, 172.3; IR (KBr) v 2150, $1750 \mathrm{~cm}^{-1}$. Anal. Calcd for $\mathrm{C}_{19} \mathrm{H}_{30} \mathrm{O}_{5} \mathrm{Si}$ : C, 62.26; H, 8.26. Found: C, 62.07; H, 8.28.

Ethyl 4-acetoxy-6-(phenylethynyl)-5-oxabicyclo[4.4.0]decanecarboxylate (1c). Prepared from $\mathbf{6 a}^{15}$ (955 mg, $\left.4.22 \mathrm{mmol}\right)$ and lithium phenylacetylide $(\sim 0.35 \mathrm{M}, 5.08 \mathrm{mmol})$ following the procedure described for the synthesis of 1a. The addition of the lithium reagent was done at -78 ${ }^{\circ} \mathrm{C}$ and the reaction was allowed to proceed at $-52{ }^{\circ} \mathrm{C}$ for $2.2 \mathrm{~h}$. The crude product was purified by flash chromatography (silica gel, 15\%, 25\% and finally 35\% EtOAc in hexanes) to afford cis1c $(546 \mathrm{mg})$ and trans-1c (140 mg, after additional purification by HPLC). Dat a for cis-1c: ${ }^{1} \mathrm{H}$ NMR $\delta 1.27\left(\mathrm{t}, J=7.1 \mathrm{~Hz}, 3 \mathrm{H}, \mathrm{CO}_{2} \mathrm{CH}_{2} \mathrm{CH}_{3}\right), 1.53-2.22(\mathrm{~m}, 13 \mathrm{H}), 2.12\left(\mathrm{~s}, \mathrm{OCOCH}_{3}\right.$, included in $\mathrm{m}$ at $1.53-2.22), 2.33-2.62(\mathrm{~m}, 2 \mathrm{H}), 4.18\left(\mathrm{q}, J=7.1 \mathrm{~Hz}, 2 \mathrm{H}, \mathrm{CO}_{2} \mathrm{CH}_{2} \mathrm{CH}_{3}\right), 6.35$ (dd, $J=7.3$, $5.4 \mathrm{~Hz}, 1 \mathrm{H}, \mathrm{H}-4), 7.27-7.29$ (m, 3H, Ar-H), 7.41-7.45 (m, 2H, Ar- $\mathrm{H}) ;{ }^{13} \mathrm{C}$ NMR $\delta$ 14.0, 2 0.0, 21.0, 21.5, 25.3, 28.2, 28.8, 35.3, 47.5, 60.3, 74.4, 87.3, 88.2, 92.5, 122.4, 128.0, 128.1, 131.5, 168.9, 173.4; IR (neat) $v 2225,1753,1725 \mathrm{~cm}^{-1}$; HRMS calcd for $\mathrm{C}_{22} \mathrm{H}_{26} \mathrm{O}_{5} 370.1780$, found 370.1778. Data for trans-1c: HPLC (column 1, 25\% EtOAc in hexanes, $7 \mathrm{~mL} / \mathrm{min}$ ) $t_{\mathrm{R}} 24 \mathrm{~min} ;{ }^{1} \mathrm{H}$ NMR $\delta 1.19-1.31(\mathrm{~m}, 4 \mathrm{H}), 1.28\left(\mathrm{t}, J=7.1 \mathrm{~Hz}, \mathrm{CO}_{2} \mathrm{CH}_{2} \mathrm{CH}_{3}\right.$, included in $\mathrm{m}$ at 1.19-1.31), $1.44-2.13(\mathrm{~m}, 8 \mathrm{H}), 2.05-2.10(\mathrm{~m}, 5 \mathrm{H}), 2.09\left(\mathrm{~s}, \mathrm{OCOCH}_{3}\right.$, included in $\mathrm{m}$ at 2.05-2.10), $2.16(\mathrm{td}$, $J=13.6,9.8 \mathrm{~Hz}$, included in $\mathrm{m}$ at $2.05-2.10), 2.72-2.85(\mathrm{~m}, 1 \mathrm{H}), 4.22(\mathrm{q}, J=7.1 \mathrm{~Hz}, 2 \mathrm{H}$, $\left.\mathrm{CO}_{2} \mathrm{CH}_{2} \mathrm{CH}_{3}\right), 6.48(\mathrm{dd}, J=10.1,3.1 \mathrm{~Hz}, 1 \mathrm{H}, \mathrm{H}-4), 7.30-7.35(\mathrm{~m}, 3 \mathrm{H}, \mathrm{Ar}-\mathrm{H}), 7.44-7.50(\mathrm{~m}, 2 \mathrm{H}$, Ar- $H) ;{ }^{13} \mathrm{C}$ NMR $\delta 14.2,21.2,22.2,23.1,28.1,30.5,33.3,33.3,49.8,60.3,78.7,87.7,89.9,92$. 122.3, 128.3, 128.5, 131.6, 169.3, 172.5; IR (neat) v 2225, 1753, $1725 \mathrm{~cm}^{-1}$; HRMS calcd for $\mathrm{C}_{22} \mathrm{H}_{26} \mathrm{O}_{5} 370.1780$, found 370.1775 .

Ethyl 4-methoxy-cis-5-oxabicyclo[4.4.0]decanecarboxylate (2). A solution of 7a (273 mg, $1.08 \mathrm{mmol})$ in $\mathrm{MeOH} / \mathrm{HCl}(98: 2,4.3 \mathrm{~mL})$ was refluxed for $3 \mathrm{~h}$. Saturated $\mathrm{K}_{2} \mathrm{CO}_{3}(5 \mathrm{~mL})$ was added until basic $\mathrm{pH}$ and $\mathrm{MeOH}$ was evaporated at reduced pressure. The aqueous layer was extracted with EtOAc $(100,25$ and $25 \mathrm{~mL})$ and the combined organic layers were washed with brine $(10 \mathrm{~mL})$ and dried $\left(\mathrm{Na}_{2} \mathrm{SO}_{4}\right)$. The crude after evaporation of the solvent was purifieby flash chromatography (silica gel, 7\% EtOAc in hexanes) to yield $2\left(230 \mathrm{mg}, 79 \%\right.$, one isomer): ${ }^{1} \mathrm{H}$ NMR $\delta 1.21\left(\mathrm{t}, J=7.1 \mathrm{~Hz}, 3 \mathrm{H}, \mathrm{CO}_{2} \mathrm{CH}_{2} \mathrm{CH}_{3}\right), 1.28-2.24(\mathrm{~m}, 11 \mathrm{H}), 2.44(\mathrm{td}, J=13.3,4.5 \mathrm{~Hz}$, $1 \mathrm{H}), 2.50$ (s, $\left.1 \mathrm{H}, \mathrm{H}-2^{\prime}\right), 3.42$ (s, $\left.3 \mathrm{H}, \mathrm{OCH}_{3}\right), 4.10$ (q, J = 7.1 Hz, $2 \mathrm{H}, \mathrm{CO}_{2} \mathrm{CH}_{2} \mathrm{CH}_{3}$ ), 4.85-4.90 (m, 1H, H-4); ${ }^{13} \mathrm{C}$ NMR $\delta 14.0,20.0,21.6,26.2,28.1,28.8,35.5,47.4,55.9,60.3,72.5,74.6$, 83.9, 99.9, 173.8; IR (neat) v 3255, 2101, $1733 \mathrm{~cm}^{-1}$. Anal. Calcd for $\mathrm{C}_{15} \mathrm{H}_{22} \mathrm{O}_{4}: \mathrm{C}, 67.63 ; \mathrm{H}$, 8.33. Found: C, $67.72 ; \mathrm{H}, 8.40$.

Ethyl 6-ethynyl-4-hydroxy-5-oxabicyclo[4.3.0]nonanecarboxylate (7d). A mixture of $6 b^{16}$ 
(0.223 g, $1.07 \mathrm{mmol})$, benzotriazole $(0.127 \mathrm{~g}, 1.07 \mathrm{mmol})$, dibenzylamine $(0.20 \mathrm{~mL}, 1.07 \mathrm{mmol})$ and $4 \AA$ molecular sieves $(4 \mathrm{~g})$ in benzene $(30 \mathrm{~mL})$ was stirred for $12 \mathrm{~h}$ at $25{ }^{\circ} \mathrm{C}$ and filtered through Celite. The solvent was removed at reduced pressure and the residue was dissolved in THF $(30 \mathrm{~mL})$. To the well stirred solution at $-78{ }^{\circ} \mathrm{C}$ was added via cannula lithium acetylide ${ }^{17}$ (0.042 $\mathrm{M}, 1.26 \mathrm{mmol})$ and the mixture was stirred at $-78{ }^{\circ} \mathrm{C}$ for $30 \mathrm{~min}$. The solution was allowed to reach room temperature and stirred further $3 \mathrm{~h}$. After adding $3 \mathrm{M} \mathrm{HCl}(15 \mathrm{~mL})$ the layers were separated, the organic layer was washed with brine $(15 \mathrm{~mL})$ and dried $\left(\mathrm{Na}_{2} \mathrm{SO}_{4}\right)$. The crude after evaporation was purified by flash chromatography (silica gel, 35\% EtOAc in hexanes) to yield $0.123 \mathrm{~g}(44 \%)$ of lactol $7 \mathbf{d}\left(\sim 9: 1\right.$ diastereomeric mixture) as an oil: ${ }^{1} \mathrm{H}$ NMR $\delta$ $1.26\left(\mathrm{t}, J=7.1 \mathrm{~Hz}, 3 \mathrm{H}, \mathrm{CH}_{3}\right.$, major isomer, overlapped with signals from the minor isomer), 1.47-1.64 (m, 1H), 1.80-2.14 (m, 7H), 2.29-2.55 (m, 3H), 2.53 (s, acetylenic, major diast., included in $\mathrm{m}$ at 2.29-2.55), 2.98 (br s, $\left.W_{1 / 2}=10.2 \mathrm{~Hz}, 1 \mathrm{H}, \mathrm{OH}\right), 4.09-4.21\left(\mathrm{~m}, 2 \mathrm{H}, \mathrm{OCH}_{2}\right)$, $5.13(\mathrm{~d}, J=9.5 \mathrm{~Hz}, \mathrm{H}-4$, major diast.) and 5.23-5.25 (m, H-4, minor diast.) (total $1 \mathrm{H})$; ${ }^{13} \mathrm{C} \mathrm{NMR}$ (major diast.) $\delta 13.9,21.5,24.7,27.3,30.6,40.6,55.9,60.8,75.3,80.9,81.0,92.8,174.4$; IR (neat) $3430,3260,2100,1730,1720 \mathrm{~cm}^{-1}$.

Ethyl 6-(hex-1-ynyl)-4-hydroxy-5-oxabicyclo[4.3.0]nonanecarboxylate (7e). To a stirred solution of hex-1-ynyl lithium $(0.11 \mathrm{M}, 11.39 \mathrm{mmol}){ }^{1}$ in THF $(100 \mathrm{~mL})$ at $-78{ }^{\circ} \mathrm{C}$ under Ar was added via cannula a solution of ethyl 3-( $N$-cyclohexylimino $)$ propyl-2oxocyclopentanecarboxylate [from cyclohexylamine $(1.20 \mathrm{~mL}, 10.85 \mathrm{mmol})$ and $6 \mathrm{~b}^{16}(2.30 \mathrm{~g}$, $10.85 \mathrm{mmol})]$ in THF $(300 \mathrm{~mL})$. The mixture was stirred for $2 \mathrm{~h}$ and then was allowed to reach room temperature. The solution was extracted successively with $1 \mathrm{M} \mathrm{HCl}(15 \mathrm{~mL}), 1 \mathrm{M} \mathrm{NaOH}$ $(5 \mathrm{~mL})$ and brine $(10 \mathrm{~mL})$. The aqueous layers were back extracted with ether $(3 \mathrm{x} 20 \mathrm{~mL})$ and the combined organic extracts were dried $\left(\mathrm{Na}_{2} \mathrm{SO}_{4}\right)$. The crude after evaporation was purified by flash chromatography (silica gel, 20\% EtOAc in hexanes) to yield $1.05 \mathrm{~g}(33 \%, 17: 1$ diastereomeric mixture) of lactol 7e as an oil: ${ }^{1} \mathrm{H}$ NMR $\delta 0.88\left(\mathrm{t}, J=7.1 \mathrm{~Hz}, 3 \mathrm{H}, \mathrm{CH}_{3}\right), 1.24(\mathrm{t}, J$ $=7.2 \mathrm{~Hz}, 3 \mathrm{H}, \mathrm{OCH}_{2} \mathrm{CH}_{3}$, major isomer, overlapped with signals from the minor isomer), $1.32-1.60(\mathrm{~m}, 4 \mathrm{H}), 1.77-2.09(\mathrm{~m}, 8 \mathrm{H}), 2.17\left(\mathrm{t}, J=6.8 \mathrm{~Hz}, 2 \mathrm{H}, \mathrm{CH}_{2}-\mathrm{C} \_\right), 2.27-2.48(\mathrm{~m}, 2 \mathrm{H})$, $3.33(\mathrm{~d}, J=6.0 \mathrm{~Hz}, 1 \mathrm{H}, \mathrm{OH}), 4.01-4.18\left(\mathrm{~m}, 2 \mathrm{H}, \mathrm{OCH}_{2} \mathrm{CH}_{3}\right), 5.10(\mathrm{ddd}, J=9.6,6.0,1.9 \mathrm{~Hz}, 1 \mathrm{H}$, $\mathrm{H}-4) ;{ }^{13} \mathrm{C}$ NMR (major diast.) $\delta 13.5,14.0,18.3,21.7,21.8,24.8,27.7,30.6,40.9,56.1,60.6$, 77.1, 81.6, 88.0, 92.8, 174.7; IR (neat) 3420, 2230, $1730 \mathrm{~cm}^{-1}$; HRMS calcd for $\mathrm{C}_{17} \mathrm{H}_{26} \mathrm{O}_{4}$ $277.1804(\mathrm{M}-\mathrm{OH})$, found 277.1804.

Ethyl 4-acetoxy-6-ethynyl-5-oxabicyclo[4.3.0]nonanecarboxylate (1d). The acetylation procedure described for the preparation of 1a was applied to $7 \mathbf{d}(0.260 \mathrm{~g}, 1.09 \mathrm{mmol})$. The crude product was purified by flash chromatography (silica gel, 15\% EtOAc in hexanes) to yield 0.265 $\mathrm{g}(87 \%)$ of acetate $1 \mathrm{~d}$ as an oil: ${ }^{1} \mathrm{NMR} \delta 1.20\left(\mathrm{t}, J=7.1 \mathrm{~Hz}, 3 \mathrm{H}, \mathrm{OCH}_{2} \mathrm{CH}_{3}\right), 1.54-2.12(\mathrm{~m}$, $11 \mathrm{H}), 2.03$ (s, $\mathrm{CH}_{3} \mathrm{CO}$, included in $\mathrm{m}$ at 1.54-2.12), 2.28-2.49 (m, 2H), 2.56 (s, 1H, acetylenic), 4.09 (q, $J=7.1 \mathrm{~Hz}, 2 \mathrm{H}, \mathrm{OCH}_{2} \mathrm{CH}_{3}$ ), 5.97 (dd, $\left.J=9.7,2.7 \mathrm{~Hz}, 1 \mathrm{H}, \mathrm{H}-4\right) ;{ }^{13} \mathrm{C}$ NMR $\delta 13.8,20.9$, 21.4, 24.3, 24.9, 30.6, 40.2, 55.8, 60.7, 75.9, 79.9, 81.7, 91.7, 168.8, 173.8; IR (neat) 3260, 2100, $1750,1725 \mathrm{~cm}^{-1}$; HRMS calcd for $\mathrm{C}_{15} \mathrm{H}_{20} \mathrm{O}_{5}: 280.1311$, found 280.1292. 
Ethyl 4-Acetoxy-6-(hex-1-ynyl)-5-oxabicyclo[4.3.0]nonanecarboxylate (1e). The acetylation procedure described for the preparation of 1 a was applied to $7 \mathbf{e}(0.800 \mathrm{~g}, 2.72 \mathrm{mmol})$. The crude product was purified by flash chromatography (silica gel, 10\% EtOAc in hexanes) to yield 0.814 $\mathrm{g}\left(89 \%, \sim 20: 1\right.$ diastereomeric mixture) of acetate 1e as an oil: ${ }^{1} \mathrm{H}$ NMR $\delta 0.84-0.97(\mathrm{~m}, 3 \mathrm{H}$, $\left.\mathrm{CH}_{3}\right), 1.26\left(\mathrm{t}, \mathrm{J}=7.1 \mathrm{~Hz}, 3 \mathrm{H}, \mathrm{OCH}_{2} \mathrm{CH}_{3}\right.$, major isomer, overlapped with signals of the minor isomer), 1.34-2.12 (m, 15H), $2.04\left(\mathrm{~s}, \mathrm{CH}_{3} \mathrm{CO}\right.$, minor diast., included in $\mathrm{m}$ at 1.34-2.12), 2.09 (s, $\mathrm{CH}_{3} \mathrm{CO}_{2-}$, major diast., included in $\mathrm{m}$ at $\left.1.34-2.12\right), 2.21\left(\mathrm{t}, \mathrm{J}=6.9 \mathrm{~Hz}, 2 \mathrm{H}, \mathrm{CH}_{2}-\mathrm{C}\right), 2.34-2.50$ $(\mathrm{m}, 2 \mathrm{H}), 4.07-4.19\left(\mathrm{~m}, 2 \mathrm{H}, \mathrm{OCH}_{2} \mathrm{CH}_{3}\right), 6.03$ (dd, $\left.J=9.8,2.6 \mathrm{~Hz}, 1 \mathrm{H}, \mathrm{H}-4\right) ;{ }^{13} \mathrm{C}$ NMR (major diast.) $\delta 13.4,14.0,18.2,21.1,21.6,21.7,24.5,25.2,30.5,30.7,40.5,56.1,60.6,76.1,82.6$, 88.6, 92.1, 169.0, 174.3; IR (neat) 2230, $1730 \mathrm{~cm}^{-1}$; HRMS calcd for $\mathrm{C}_{19} \mathrm{H}_{28} \mathrm{O}_{5} 336.1937$, found 336.1942 .

Ethyl 6-benzoyloxy-4-ethynyl-5-oxabicyclo[4.3.0]nonanecarboxylate (4a). To a solution of $\mathbf{6 b}^{16}(2.10 \mathrm{~g}, 10.2 \mathrm{mmol})$ in THF $(40 \mathrm{~mL})$ at $-78{ }^{\circ} \mathrm{C}$ was added via cannula over $1 \mathrm{~h}$ a solution of lithium acetylide ${ }^{17}(0.21 \mathrm{M}, 10.7 \mathrm{mmol})$ in THF $(50 \mathrm{~mL})$. The solution was stirred at $-78{ }^{\circ} \mathrm{C}$ for $90 \mathrm{~min}$ and benzoyl chloride $(2.4 \mathrm{~mL}, 20.45 \mathrm{mmol})$ was added neat. After allowing the mixture to reach room temperature, $\mathrm{H}_{2} \mathrm{O}(20 \mathrm{~mL})$ was added, the aqueous layer was extracted with ether $(2 \times 20 \mathrm{~mL})$ and the combined organic layers were dried $\left(\mathrm{Na}_{2} \mathrm{SO}_{4}\right)$. The crude was purified by flash chromatography (silica gel, 20\% EtOAc in hexanes) to yield $1.20 \mathrm{~g}(35 \%)$ of $4 \mathbf{a}$ as a colorless solid: $\mathrm{mp} 163-165{ }^{\circ} \mathrm{C} ;{ }^{1} \mathrm{H}$ NMR $\delta 1.21\left(\mathrm{t}, J=7.1 \mathrm{~Hz}, 3 \mathrm{H}, \mathrm{OCH}_{2} \mathrm{CH}_{3}\right), 1.87-2.09$ (m, $7 \mathrm{H}), 2.43(\mathrm{~d}, J=2.2 \mathrm{~Hz}, 1 \mathrm{H}$, acetylenic), 2.47-2.61 (m, 2H), 2.81-2.90 (m, 1H), 4.06-4.25 (m, $\left.2 \mathrm{H}, \mathrm{OCH}_{2} \mathrm{CH}_{3}\right), 4.40$ (dt, $\left.J=8.3,2.2 \mathrm{~Hz}, 1 \mathrm{H}, \mathrm{H}-4\right), 7.40-7.59(\mathrm{~m}, 3 \mathrm{H}), 7.98-8.02(\mathrm{~m}, 2 \mathrm{H}) ;{ }^{13} \mathrm{C}$ NMR $\delta 14.1,20.4,24.9,26.8,29.0,36.5,53.4,61.0,62.0,73.3,82.1,109.3,128.4,129.8,130.2$, 133.2, 163.3, 174.1; IR (neat) 3300, $1740 \mathrm{~cm}^{-1}$. Anal. Calcd for $\mathrm{C}_{20} \mathrm{H}_{22} \mathrm{O}_{5}: \mathrm{C}, 70.16 ; \mathrm{H}, 6.48$. Found: C, 70.36; H, 6.62.

Ethyl 6-benzoyloxy-4-(hex-1-ynyl)-5-oxabicyclo[4.3.0]nonanecarboxylate (4b). The previous procedure was applied to $\mathbf{6 b}^{16}(2.30 \mathrm{~g}, 10.85 \mathrm{~m} \mathrm{~mol})$ and hex-1-ynyl lithium ${ }^{1}$ (11.39 mmol). The crude was purified by flash chromatography (silica gel, 10\% EtOAc in hexanes) to yield $1.31 \mathrm{~g}$ (30\%, 17:1 diastereomeric mixture) of benzoate $\mathbf{4 b}$ as an oil: ${ }^{1} \mathrm{H}$ NMR $\delta 0.87(\mathrm{t}, J=6.8 \mathrm{~Hz}, 3 \mathrm{H}$, $\left.\mathrm{CH}_{3}\right), 1.08\left(\mathrm{t}, J=7.1 \mathrm{~Hz}, \mathrm{OCH}_{2} \mathrm{CH}_{3}\right.$, minor diast.) and 1.17-1.51 (m) (total 7H), $1.20(\mathrm{t}, J=7.1$ $\mathrm{Hz}, \mathrm{OCH}_{2} \mathrm{CH}_{3}$, major diast., included in $\mathrm{m}$ at 1.17-1.51), 1.70-2.04 (m, 7H), $2.17(\mathrm{t}, \mathrm{J}=6.9 \mathrm{~Hz}$, $\left.2 \mathrm{H}, \mathrm{CH}_{2}-\mathrm{C}_{-}\right), 2.43-2.60(\mathrm{~m}, 2 \mathrm{H}), 2.71-2.87(\mathrm{~m}, 1 \mathrm{H}), 4.05-4.24\left(\mathrm{~m}, 2 \mathrm{H}, \mathrm{OCH}_{2} \mathrm{CH}_{3}\right), 4.37-4.42$ $(\mathrm{m}, 1 \mathrm{H}, \mathrm{H}-4), 7.35-7.64(\mathrm{~m}, 3 \mathrm{H}), 8.00(\mathrm{~d}, J=8.0 \mathrm{~Hz}$, major diast.) and $8.13(\mathrm{~d}, J=8.0 \mathrm{~Hz}$, minor diast.) (total $2 \mathrm{H}) ;{ }^{13} \mathrm{C}$ NMR (major diast.) $\delta 13.2,13.8,18.2,20.1,21.6,24.7,27.1,28.6$, 30.1, 36.1, 53.0, 60.6, 62.2, 78.1, 85.4, 109.0, 128.1, 129.4, 130.0, 132.8, 163.0, 173.9; IR (neat) $2230,1730 \mathrm{~cm}^{-1}$; HRMS calcd for $\mathrm{C}_{24} \mathrm{H}_{30} \mathrm{O}_{5} 398.2093$, found 398.2068 .

\section{General procedure for reactions of 1, 2, 4 with $\mathrm{SmI}_{2} / \mathbf{P d}\left(\mathrm{PPh}_{3}\right)_{4}$.}

In a typical experiment, a solution of the substrate $(0.50 \mathrm{mmol})$ and $\mathrm{Pd}\left(\mathrm{PPh}_{3}\right)_{4}(0.025 \mathrm{mmol})$ in THF (4 mL) was added to a solution of $\mathrm{SmI}_{2}{ }^{2 \mathrm{~b}}(1.1 \mathrm{mmol})$ in THF $(11 \mathrm{~mL})$ at room temperature. The resulting mixture was stirred until total conversion of the substrate (as determined by TLC) 
and saturated $\mathrm{K}_{2} \mathrm{CO}_{3}(5 \mathrm{~mL})$ was added. The aqueous layer was extracted with EtOAc ( $4 \mathrm{x}$ $35 \mathrm{~mL})$, the combined organic layers were washed with brine $(3 \mathrm{~mL})$ and dried $\left(\mathrm{Na}_{2} \mathrm{SO}_{4}\right)$. The crude product obtained after evaporation was purified by flash chromatography as specified for the individual cases.

Ethyl 6-ethynyl-cis-5-oxabicyclo[4.4.0]dec-3-enecarboxylate (8a). The general procedure was followed from 1a (136 mg, $0.49 \mathrm{mmol})$. Reaction time: $62 \mathrm{~h}$. The crude product was purified by flash chromatography (silica gel, 5\% EtOAc in hexanes, then 40\% EtOAc in hexanes) to afford 8a $(75 \mathrm{mg}, 65 \%)$ and 7a $(7 \mathrm{mg}, 6 \%)$. Data for 8a: ${ }^{1} \mathrm{H}$ NMR $\delta 1.24-1.33(\mathrm{~m}, 4 \mathrm{H}), 1.26(\mathrm{t}, J=7.1$ $\mathrm{Hz}, \mathrm{CO}_{2} \mathrm{CH}_{2} \mathrm{CH}_{3}$ included in $\mathrm{m}$ at 1.24-1.33), 1.52-1.64 (m, 4H), 1.72-1.77 (m, 2H), 1.94-2.03 $(\mathrm{m}, 2 \mathrm{H}), 2.42\left(\mathrm{~s}, 1 \mathrm{H}, \mathrm{H}-2^{\prime}\right), 2.42-2.62(\mathrm{~m}, 2 \mathrm{H}), 4.17\left(\mathrm{q}, J=7.1 \mathrm{~Hz}, \mathrm{CO}_{2} \mathrm{CHCH}_{3}\right)$ and $4.18(\mathrm{q}, J$ $\left.=7.1 \mathrm{~Hz}, \mathrm{CO}_{2} \mathrm{CHCH}_{3}\right)($ total $2 \mathrm{H}), 4.80(\mathrm{dt}, J=5.7,2.3 \mathrm{~Hz}, 1 \mathrm{H}, \mathrm{H}-3), 6.26(\mathrm{dt}, J=5.7,1.7 \mathrm{~Hz}$, $1 \mathrm{H}, \mathrm{H}-4) ;{ }^{13} \mathrm{C} \mathrm{NMR} \delta$ 14.1, 20.4, 21.9, 29.3, 29.7, 34.1, 47.1, 60.5, 71.5, 72.3, 84.5, 99.1, 140.1, 173.5; IR (neat) v 3290, 1740, $1670 \mathrm{~cm}^{-1}$; HRMS calcd for $\mathrm{C}_{14} \mathrm{H}_{18} \mathrm{O}_{3} 234.1256$, found 234.1257.

Ethyl 6-(trimethylsilylethynyl)-cis-5-oxabicyclo[4.4.0]dec-3-enecarboxylate $(8 \mathrm{~b}) . \quad$ The general procedure was followed from $\mathbf{1 b}(110 \mathrm{mg}, 0.30 \mathrm{mmol})$ for $16 \mathrm{~h}$. The crude product was purified by flash chromatography (silica gel, 2.5\% EtOAc in hexanes) to yield $\mathbf{8 b}$ (58 $\mathrm{mg}, 63 \%$ ) as an oil: ${ }^{1} \mathrm{H}$ NMR $\delta 0.12\left(\mathrm{~s}, 9 \mathrm{H}, \mathrm{Si}\left(\mathrm{CH}_{3}\right)_{3}\right), 1.25\left(\mathrm{t}, \mathrm{J}=7.1 \mathrm{~Hz}, 3 \mathrm{H}, \mathrm{CO}_{2} \mathrm{CH}_{2} \mathrm{CH}_{3}\right), 1.34-1.73$ $(\mathrm{m}, 6 \mathrm{H}), 1.90-2.00(\mathrm{~m}, 2 \mathrm{H}), 2.40-2.56(\mathrm{~m}, 2 \mathrm{H}), 4.15\left(\mathrm{q}, J=7.1 \mathrm{~Hz}, 2 \mathrm{H}, \mathrm{CO}_{2} \mathrm{CH}_{2} \mathrm{CH}_{3}\right)$, 4.69-4.75 (m, 1H, H-3), 6.21 (apparent d, $J=6.0 \mathrm{~Hz}, 1 \mathrm{H}, \mathrm{H}-4) ;{ }^{13} \mathrm{C}$ NMR $\delta-0.1,14.1,20.5$, 21.7, 29.0, 29.9, 34.0, 47.2, 60.4, 72.6, 88.2, 98.7, 106.1, 140.0, 173.5; IR (neat) v 3065, 2169, $1736,1663 \mathrm{~cm}^{-1}$; HRMS calcd for $\mathrm{C}_{17} \mathrm{H}_{26} \mathrm{O}_{3} \mathrm{Si} 306.1651$, found 306.1646.

Ethyl 6-(phenylethynyl)-cis-5-oxabicyclo[4.4.0]dec-3-enecarboxylate (8c). A solution of 1c (115 mg, $0.38 \mathrm{mmol})$ in THF (4 mL) was added to a solution of $\mathrm{SmI}_{2}(0.1 \mathrm{M}$ in THF, $9.5 \mathrm{~mL}$, $0.95 \mathrm{mmol}$ ) at room temperature. The mixture was stirred for $22 \mathrm{~h}$ at the same temperature and was elaborated as specified in the general procedure. The crude product was purified by flash chromatograph(silica gel, 8\% EtOAc in hexanes) to yield 8c (72 mg, 78\%) as an oil: ${ }^{1} \mathrm{H}$ NMR $\delta$ 1.24-2.00 (m, 7H), $1.26\left(\mathrm{t}, J=7.1 \mathrm{~Hz}, \mathrm{CO}_{2} \mathrm{CH}_{2} \mathrm{CH}_{3}\right.$, included in $\mathrm{m}$ at 1.24-2.00), 2.05-2.11 (m, $2 \mathrm{H}), 2.47-2.69(\mathrm{~m}, 2 \mathrm{H}), 4.19\left(\mathrm{q}, J=7.0 \mathrm{~Hz}, \mathrm{CO}_{2} \mathrm{CHCH}_{3}\right)$ and $4.20\left(\mathrm{q}, J=7.1 \mathrm{~Hz}, \mathrm{CO}_{2} \mathrm{CHCH}_{3}\right)$ (total 2H), 4.79 (td, $J=5.9,2.2 \mathrm{~Hz}, 1 \mathrm{H}, \mathrm{H}-3), 6.29$ (d, $J=5.9 \mathrm{~Hz}, 1 \mathrm{H}, \mathrm{H}-4), 7.26-7.27$ (m, 3H, Ar-H), 7.38-7.42 (m, 2H, Ar-H); ${ }^{13} \mathrm{C}$ NMR $\delta$ 14.1, 20.6, 21.8, 29.3, 29.9, 47.5, 60.4, 72.8, 83.6, 90.0, 98.9, 122.9, 128.0, 131.7, 140.2, 173.5; IR (neat) v 3063, 2230, 1733, $1662 \mathrm{~cm}^{-1}$; HRMS calcd for $\mathrm{C}_{20} \mathrm{H}_{22} \mathrm{O}_{3} 310.1569$, found 310.1574 .

$\left(1 R^{*}, 4 R^{*}, 5 R^{*}\right)$-Ethyl 5-ethynyl-4-hydroxybicyclo[3.3.0]octanecarboxylate (3d). Prepared from acetate $1 \mathbf{d}(0.714 \mathrm{mmol})$ and $\mathrm{Pd}\left(\mathrm{PPh}_{3}\right)_{4}(0.036 \mathrm{mmol})$ in THF $(8 \mathrm{~mL})$ using the general procedure. Reaction time: $64 \mathrm{~h}$. The crude was purified by flash chromatography (silica gel, 35\% EtOAc in hexanes) to yield the alcohol $3 \mathbf{d}(0.134 \mathrm{~g}, 84 \%)$ as a colorless oil. The spectral sample was obtained after HPLC (column 2, 15\% EtOAc in hexanes, $6 \mathrm{~mL} / \mathrm{min}$ ): $t_{\mathrm{R}} 15 \mathrm{~min} ;{ }^{1} \mathrm{H} \mathrm{NMR} \delta$ $1.26\left(\mathrm{t}, J=7.1 \mathrm{~Hz}, 3 \mathrm{H}, \mathrm{OCH}_{2} \mathrm{CH}_{3}\right), 1.41-2.20(\mathrm{~m}, 9 \mathrm{H}), 2.18(\mathrm{~s}$, acetylenic, included in $\mathrm{m}$ at 1.41-2.20), 2.26-2.55 (m, 3H), 4.12 (q, $\left.J=7.1 \mathrm{~Hz}, 2 \mathrm{H}, \mathrm{OCH}_{2} \mathrm{CH}_{3}\right), 4.37$ (dd, $J=10.3,6.3 \mathrm{~Hz}$, 
$1 \mathrm{H}, \mathrm{H}-4) ;{ }^{13} \mathrm{C}$ NMR $\delta 14.1,26.2,31.6,32.0,35.3,38.3,56.4,60.8,63.9,70.3,80.2,88.5,175.4$; IR (neat) 3450, 2100, $1725 \mathrm{~cm}^{-1}$; HRMS calcd for $\mathrm{C}_{13} \mathrm{H}_{19} \mathrm{O}_{3}(\mathrm{M}+1) 223.1334$, found 223.1357.

Ethyl 5-ethynyl-4-oxobicyclo[3.3.0]octanecarboxylate (10). To a solution of alcohol 1d $(0.053 \mathrm{~g}, 0.238 \mathrm{mmol})$ in $\mathrm{CH}_{2} \mathrm{Cl}_{2}(6 \mathrm{~mL})$ was added PDC $(0.30 \mathrm{~g}, 0.79 \mathrm{mmol})$ and the mixture was stirred at room temperature for $60 \mathrm{~h}$, diluted with ether $(25 \mathrm{~mL})$, filtered through silica gel (70-230 mesh) and evaporated to dryness. The crude after evaporation was purified by flash chromatography (silica gel, 20\% EtOAc in hexanes) to yield the ketone $10(0.049 \mathrm{~g}, 94 \%)$ as a colorless oil: ${ }^{1} \mathrm{H}$ NMR $\delta 1.28\left(\mathrm{t}, J=7.1 \mathrm{~Hz}, 3 \mathrm{H}, \mathrm{OCH}_{2} \mathrm{CH}_{3}\right), 1.57-2.05(\mathrm{~m}, 3 \mathrm{H}), 2.12-2.33(\mathrm{~m}$, $4 \mathrm{H}), 2.29$ (s, acetylenic, included in $\mathrm{m}$ at 2.12-2.33), 2.37-2.58 (m, 3H), 2.67-2.82 (m, 1H), 4.20 (q, $\left.J=7.1 \mathrm{~Hz}, 2 \mathrm{H}, \mathrm{OCH}_{2} \mathrm{CH}_{3}\right) ;{ }^{13} \mathrm{C}$ NMR $\delta 14.1,24.1,28.2,35.4,35.8,37.6,58.8,61.1,62.4$, 73.1, 81.1, 173.9, 213.1; IR (neat) 3275, 2100, 1750, $1730 \mathrm{~cm}^{-1}$.

Reduction of ketone $\mathbf{1 0}$. To a solution of $10(22 \mathrm{mg}, 0.10 \mathrm{mmol})$ in ethanol $(5 \mathrm{~mL})$ at $0{ }^{\circ} \mathrm{C}$ was added $\mathrm{NaBH}_{4}(5 \mathrm{mg}, 0.13 \mathrm{mmol})$. The mixture was stirred for $30 \mathrm{~min}$ and water $(2 \mathrm{~mL})$ was added. The mixture was extracted with ether $(3 \times 20 \mathrm{~mL})$ and the organic extracts were dried $\left(\mathrm{Na}_{2} \mathrm{SO}_{4}\right)$. The crude after evaporation was purified by flash chromatography (silica gel, 5\% EtOAc in hexanes and then 40\% EtOAc in hexanes) to yield the alcohols 3d, 3d' (15 mg, 69\%, 1:1 diastereomeric mixture) as a colorless oil. The spectral sample was obtained after HPLC (column 2, 20\% EtOAc in hexanes, $6 \mathrm{~mL} / \mathrm{min}$ ): $t_{\mathrm{R}} 9$ (3d) and 10 (3d') $\mathrm{min}$; ${ }^{1} \mathrm{H}$ NMR (mixture of isomers) $\delta 1.28$ and $1.29\left(\mathrm{t}, J=7.1 \mathrm{~Hz}, 3 \mathrm{H}, \mathrm{OCH}_{2} \mathrm{CH}_{3}\right), 1.39-2.17(\mathrm{~m}, 8 \mathrm{H}), 2.31-2.68(\mathrm{~m}, 2 \mathrm{H})$, 2.20 and 2.37 (s, $1 \mathrm{H}$, acetylenic), 2.83 (d, $J=8.2 \mathrm{~Hz}, \mathrm{OH}$, one isomer), 3.81-3.88 (m, H-4, 3d'), 4.11-4.22 (m, 2H, $\mathrm{OCH}_{2} \mathrm{CH}_{3}$ ), 4.40 (br t, H-4, 3d); ${ }^{13} \mathrm{C}$ NMR (mixture of isomers) $\delta$ 14.(3d), 25.3 (3d'), 26.2 (3d), 31.6 (3d'), 32.1 (3d), 33.6 (3d'), 34.0 (3d'), 35.3 (3d), 37.9 (3d'), 38.3 (3d), 39.8 (3d'), 56.5 (3d), 59.4 (3d'), 60.8 (3d), 61.1 (3d'), 63.9 (3d), 64.3 (3d'), 70.4 (3d), 74.1 (3d'), 79.2 (3d'), 80.3 (3d), 84.7 (3d'), 88.5 (3d), 175.3 (3d), 176.0 (3d'); GC-MS $t_{\mathrm{R}} 8.65$ (3d) and 8.82 (3d') $\min$.

Ethyl 6-(hex-1-ynyl)-5-oxabicyclo[4.3.0]non-3-enecarboxylate (8e). Prepared from 1e $(0.625 \mathrm{mmol})$ and $\mathrm{Pd}\left(\mathrm{PPh}_{3}\right)_{4}(0.031 \mathrm{mmol})$ in THF $(8 \mathrm{~mL})$ following the general procedure. Reaction time: $77 \mathrm{~h}$. The crude was purified by flash chromatography (silica gel, hexanes) to yield the ether $8 \mathbf{e}(0.152 \mathrm{~g}, 88 \%)$ as a colorless oil: ${ }^{1} \mathrm{H}$ NMR $\delta 0.85\left(\mathrm{t}, J=7.1 \mathrm{~Hz}, 3 \mathrm{H}, \mathrm{CH}_{3}\right)$, $1.23\left(\mathrm{t}, J=7.1 \mathrm{~Hz}, 3 \mathrm{H}, \mathrm{OCH}_{2} \mathrm{CH}_{3}\right), 1.29-1.48(\mathrm{~m}, 4 \mathrm{H}), 1.66-2.10(\mathrm{~m}, 6 \mathrm{H}), 2.15(\mathrm{t}, J=6.8 \mathrm{~Hz}$, $2 \mathrm{H}, \mathrm{CH}_{2} \mathrm{C} \_$) $2.26-2.38(\mathrm{~m}, 1 \mathrm{H}), 2.64(\mathrm{ddd}, J=17.9,2.6,2.5 \mathrm{~Hz}, 1 \mathrm{H}, \mathrm{H}-2), 4.12(\mathrm{q}, J=7.1 \mathrm{~Hz}$, $\left.1 \mathrm{H}, \mathrm{OCHCH}_{3}\right), 4.13\left(\mathrm{q}, J=7.1 \mathrm{~Hz}, 1 \mathrm{H}, \mathrm{OCHCH}_{3}\right), 4.69$ (ddd, $J=6.2,5.0,2.6 \mathrm{~Hz}, 1 \mathrm{H}, \mathrm{H}-3$ ), 6.21 (ddd, $J=6.2,2.5,2.5 \mathrm{~Hz}, 1 \mathrm{H}, \mathrm{H}-4) ;{ }^{13} \mathrm{C}$ NMR $\delta 13.4,14.0,18.3,20.4,21.7,23.7,30.5$, 31.7, 38.8, 54.9, 60.6, 77.9, 78.8, 85.8, 97.8, 139.7, 173.9; IR (neat) 2230, 1730 (f, $\mathrm{C}=\mathrm{O}) \mathrm{cm}^{-1}$; HRMS calcd for $\mathrm{C}_{17} \mathrm{H}_{24} \mathrm{O}_{3} 276.1735$, found 276.1732 .

Ethyl 4-(hex-1-ynyl)-5-oxabicyclo[4.3.0]non-6-enecarboxylate (9b). Prepared from 4b $(0.606 \mathrm{mmol})$ and $\mathrm{Pd}\left(\mathrm{PPh}_{3}\right)_{4}(0.031 \mathrm{mmol})$ in THF $(8 \mathrm{~mL})$ following the general procedure. Reaction time: $19 \mathrm{~h}$. The crude after evaporation was purified by flash chromatography (silica 
gel, 5\% EtOAc in hexanes) to yield in order of elution the ether $9 \mathrm{~b}(0.063 \mathrm{~g}, 37 \%)$ and recovered starting material $\mathbf{4 b}(0.077 \mathrm{~g}, 32 \%)$ as colorless oils. Data for $9 \mathbf{b}:{ }^{1} \mathrm{H}$ NMR $\delta 0.88(\mathrm{t}, J=7.0$ $\left.\mathrm{Hz}, 3 \mathrm{H}, \mathrm{CH}_{3}\right), 1.23\left(\mathrm{t}, J=7.1 \mathrm{~Hz}, 3 \mathrm{H}, \mathrm{OCH}_{2} \mathrm{CH}_{3}\right), 1.26-1.52(\mathrm{~m}, 4 \mathrm{H}), 1.60-2.44(\mathrm{~m}, 10 \mathrm{H})$, 4.03-4.29 (m, 2H, $\left.\mathrm{OCH}_{2} \mathrm{CH}_{3}\right), 4.84$ (m, 1H, H-4), 5.17 (br s, $\left.W_{1 / 2}=8.0 \mathrm{~Hz}, 1 \mathrm{H}, \mathrm{H}-7\right)$; ${ }^{13} \mathrm{C} \mathrm{NMR}$ $\delta 13.5,14.1,18.2,21.7,25.8,27.9,29.9,30.6,36.8,51.5,60.8,67.8,77.5,87.6,109.4,152.7$, 175.0; IR (neat) 3060, 2210, $1730 \mathrm{~cm}^{-1}$; HRMS calcd for $\mathrm{C}_{17} \mathrm{H}_{24} \mathrm{O}_{3} 277.1804(\mathrm{M}+1$ ), found 277.1803 .

\section{Acknowledgments}

Financial support by the Dirección General de Investigación Científica y Técnica (DGICYT PB89-0412, PB92-0449 and PB95-0344) and by the Universidad del País Vasco (UPV 170.3100133/89, UPV 170.310-EC021/92 and UPV 170.310-EC216/97) is gratefully acknowledged. We also thank the Departamento de Educación, Universidades e Investigación (Gobierno Vasco, Spain) for Fellowships to R.F. and B. L.

\section{References}

1. Aurrecoechea, J. M.; Fañanás, R.; Arrate, M.; Gorgojo, J. M.; Aurrekoetxea, N. J. Org. Chem. 1999, 64, 1893.

2. Recent reviews on $\mathrm{SmI}_{2}$ synthetic applications: (a) Molander, G. A. Chem. Rev. 1992, 92, 29. (b) Molander, G. A. In Organic Reactions; L. A. Paquette, Ed.; John Wiley \& Sons, New York: 1994; Vol. 46; p 211. (c) Molander, G. A.; Harris, C. R. Chem. Rev. 1996, 96, 307. (d) Molander, G. A.; Harris, C. R. Tetrahedron 1998, 54, 3321. (e) Krief, A.; Laval, A. M. Chem. Rev. 1999, 99, 745.

3. Tabuchi, T.; Inanaga, J.; Yamaguchi, M. Chem. Lett. 1987, 2275.

4. Aurrecoechea, J. M.; Lopez, B. Tetrahedron Lett. 1998, 39, 2857.

5. Aurrecoechea, J. M.; Arrate, M.; López, B. In 12th International Conference on Organic Synthesis (ICOS-12); Book of Abstracts: Venezia (Italy), 1998, 60.

6. López, B. Doctoral Thesis, Universidad del País Vasco, 1999.

7. A portion of this work has been communicated: Aurrecoechea, J. M.; Fañanás-San Antón, R. J. Org. Chem. 1994, 59, 702.

8. Reetz, M. T.; Wenderoth, B.; Peter, R. J. Chem. Soc., Chem. Commun. 1983, 406.

9. Recent reviews on synthetic applications of benzotriazoles: (a) Katritzky, A. R.; Lan, X. F.; Yang, J. Z.; Denisko, O. V. Chem. Rev. 1998, 98, 409. (b) Katritzky, A. R.; Henderson, S. A.; Yang, B. Z. J. Heterocycl. Chem. 1998, 35, 1123. (c) Katritzky, A. R.; Piff 1, M.; Lang, H.; Anders, E. Chem. Rev.1999, 99, 665.

10. See, for example, the discussion in: Curran, D. P.; Gu, X.; Zhang, W.; Dowd, P. 
Tetrahedron 1997, 53, 9023.

11. Brown, H. C.; Kramer, G. W.; Levy, A. B.; Midland, M. M. Organic Synthesis Via Boranes; Wiley \& Sons: New York, 1975.

12. Molander, G. A.; Etter, J. B. J. Org. Chem.1986, 51, 1778.

13. Perrin, D. D.; Armarego, W. F. L. Purification of Laboratory Chemicals; 3rd ed.; Pergamon Press: Oxford, 1988.

14. Still, W. C.; Kahn, M.; Mitra, A. J. Org. Chem. 1978, 43, 2923.

15. Cope, A. C.; Synerholm, M. E. J. Am. Chem. Soc. 1950, 72, 5228.

16. Prepared following the procedure described in ref 15 for $\mathbf{6 a}$.

17. Midland, M. M.; McLoughlin, J. I.; Werley, R. T. Org. Synth. 1989, 68, 14. 